\title{
Humus Materials and Moringa (Moringa oleifera Lam.) Leaf Extract Modulate the Harmful Effect of Soil Salinity Stress in Sudan Grass (Sorghum vulgare L.)
}

\author{
E.M. Desoky ${ }^{(1) \#}$, A.M. Merwad ${ }^{(2)}$, Seham A. Ibrahim ${ }^{(1)}$ \\ (1)Agriculture Botany Department, Faculty of Agriculture, Zagazig University, \\ Zagazig, Egypt; (2)Soil Science Department, Faculty of Agriculture, Zagazig \\ University, Zagazig, Egypt.
}

\begin{abstract}
$\mathbf{T}$ HE EFFECT of application different components of humus (humic acid and fulvic acid) and foliar spraying with Moringa leaf extract on Sudan grass vegetative criteria, some physiological and biochemical properties grown under three levels of soil salinity was conducted. Two pot experiments were carried out under the greenhouse conditions at the farm of Faculty of Agriculture, Zagazig University, Egypt, during the growth season 2014 and 2015. Data indicated that salinity stress condition significantly decreased plant height, shoot fresh and dry weight, chlorophyll a, b and caroteniods, photochemical activity, RNA, DNA, total carbohydrates and total sugars, while increment of antioxidant enzymes, i.e., peroxidase (POX) and catalase (CAT). Application of two humus component and foliar spraying with Moringa leaf extract overcome the harmful effects of salinity stress on the above mentioned criteria of Sudan grass compared with untreated plants. Humus components and Moringa leaf extract were helpful in improving these criteria at three cuts under different salinity levels. The highest value of the above mentioned criteria was observed with application of the humic acid + fulvic acid and spraying Moringa leaf extract, while the lowest one was recorded under the control treatment.
\end{abstract}

Keywords: Sudan grass (Sorghum vulgare), Humus, Moringa leaf extract, Soil salinity stress.

\section{Introduction}

Sudan grass (Sorghum vulgare var. sudanense) is the second biggest forage crop (next to alfalfa). The genus Sorghum consist of various differentiated yearly spring-sown species which bear a resemblance to maize inhabit but develop only tassels in which seeds are set (Józef \& Szydełko, 2011). Sorghum, being a $\mathrm{C}_{4}$ species, is an efficient employ of radiation and solar heat. It is resistant to drought, tolerates both alkaline and salinization soils (Śliwiński \& Brzoska, 2008).

Salinity is an essential abiotic stress factor that causes counteractive effects on plant growth and productivity. It is appraise that about $7 \%$ of the world's land is affected by salinity stress which gravely impairs the plant productivity of at least
$20 \%$ of irrigated land worldwide (Munns \& Tester, 2008). High salinity causes disequilibrium ion, osmotic stress, as well as oxidative stress in tissues (Zhu, 2001) and activated many genes expression in tomato seedling after exposed to salinity (Ouyang et et al., 2007). The reduction in crop production under soil salinity condition may be due to of photosynthetic processes (Pitman \& Läuchli, 2002). Actually, saltiness dishearten involved of specific enzymes for photosynthetic pigments synthesis, causing a decrease in chlorophyll content (Giri \& Mukerji, 2004 and Sheng et al., 2008). Also, salt stress caused reducing photosynthetic rate which can stimulate an over-reduction of the reaction centers in photosystem II (PSII) and this may destruction the photosynthetic machinery if the plant that is unable to consume the excess energy (Baker, 
2008). The main effect of salinity has been attributed to the reduction water potential of soil or the enhance concentration of ion in plant cells to levels that interfere with metabolism (Kalaji \& Pietkiewicz, 1993). Therefore, it is necessary to develop strategies to initiate salt resistance in plants against the adverse conditions. Numerous physiological and agronomic practices have been performed to enhance salinity stress resilience in various crops including breeding programs. However, commercial success has been limited. As alternatives, antioxidants substances plant and growth regulators (Desoky \& Merwad, 2015; Rady \& Hemida, 2016 and Desoky et al., 2017, 2018), plant biostimulants/extract (Howladar, 2014) and humic substances (Rady et al., 2016 a and Desoky et al., 2018) have been widely applied with agricultural crops to alleviate the adverse effects of salinity stress.

Humic substances are easily found in soils (Mackowiak et al., 2001 and Ulukan, 2008 b) and directly and indirectly improve plant growth (Nardi et al., 2002 and Cimrin \& Yilmaz, 2005). They have indirect effects on plant development since they can enhance soil properties, for example, collection, air circulation, porousness, water holding limit, hormonal action, microbial development, natural issue (OM) mineralization, solubilization and accessibility of microelement and macroelements (Chen \& Aviad, 1990; Ayuso et al., 1996 and Sharif et al., 2002). Directly, influence the procedures related with the takeup and humic substances transport into the plant tissues (Nardi et al., 2002).

Moringa leaf extract (MLE) are plant development improving capacities as it is rich in aminoacid,phenols andessentialelements. Moringa genuinely shows up an endowment of nature and a "Wonder" plant having incalculable advantages so that it can use to improve plants grown under a biotic stresses (Foidle et al., 2001). Leaf extract of Moringa have been showed to speed growth of wheat at seedling stage, improve resistance salinity and increase large and more fruits and generally increase yield by 20 to $35 \%$ (Fuglie, 2000). The objective of the current study is to evaluate the effect application of humus component (Humic acid and fulvic acid) with spraying Moringa leaf extract on growth characteristics, photosynthetic pigments, photochemical activity, some chemical constituents, by Sudan grass grown under salinity stress conditions.

\section{Materials and Methods}

Two pot experiments were conducted under the greenhouse conditions at the farm of Faculty of Agriculture, Zagazig University, Egypt. Sudan grass (Sorghum vulgare var. sudanense) seeds were sown during the growth season 2014 and 2015. It aims to evaluate the effect application of humus component (Humic acid and fulvic acid) with spraying Moringa leaf extract on growth characteristics, photosynthetic pigments, photochemical activity, some chemical constituents, by Sudan grass grown under salinity stress conditions. Three saline soils having almost the same near texture were collected from different location at El-Noubaria, near Alexandria, Egypt. Seeds were sterilized by using $1 \%(\mathrm{v} / \mathrm{v})$ sodium hypochlorite for $2 \mathrm{~min}$ then washed with distilled water and sown on the $20^{\text {th }}$ of March. Closed bottom plastic pots of internal dimensions $25 \mathrm{~cm}$ were filled with $10 \mathrm{~kg}$ of each saline soil (3.01, $\left.6.12,12.33 \mathrm{dSm}^{-1}\right)$. The physical and chemical properties of the investigated soil were determined according to Piper (1950), Black (1968) and Jackson (1973) and are shown in Table 1.

Before planting, the treatments of humus materials, i.e., humic acid (HA) and fulvic acid (FA) were thoroughly mixed with the soil samples at the rate of $0.2 \mathrm{~g} \mathrm{~kg}^{-1}$ soil. Mineral nitrogen was added as ammonium sulphate $(1.8 \mathrm{~g} / \mathrm{pot})$ three equal splits. The first was before the $1^{\text {st }}$ irrigation while the second and third splits were added after the first and second cuts, respectively from the first splits. The recommended doses of phosphorus and potassium were added; for all experimental treatments as ordinary super phosphate $(1.5 \mathrm{~g} \mathrm{P}$ /pot) before sowing. Potassium was added as potassium sulphate $(1.8 \mathrm{~g} / \mathrm{pot})$ were added before seeding.

An amount of $20 \mathrm{~g}$ of young Moringa oleifera leaves was mixed with $675 \mathrm{ml}$ of distilled water and $80 \%$ ethanol as suggested by Makkar \& Becker (1996). The suspension was stirred using a homogenizer to help maximize the amount of the extract. The solution was filtered using No.2 Whatman filter paper. Moringa leaves extract were used within five hours from cutting and extracting (if not ready to be used, the extract or the solution prepared was stored at $0^{\circ} \mathrm{C}$ and only taken out when needed for use). The chemical composition of ethanolic extracts of Moringa oleifera leaves were investigated by Fuglie (2000) 
and Moyo et al. (2011) and are represented in Table 2. Foliar spraying of Moringa extract was done in each of 2 occasions ( 20 and 40 days) from seed germination, after $1^{\text {st }}$ and $2^{\text {nd }}$ cuts at the rate of $3 \%$. Control plants were sprayed with distilled water and the spraying extract was maintained just to cover completely the plant foliage. Three cuts were taken from the sorghum and each cut was taken at age 60 day.
The experiment included 24 treatments in 6 replicates, so the experiment contained 144 pots. The experimental design was a split-split plot with three soil salinities (S1, S2 and S3) as main-plots, two HM levels ( 0 and $0.2 \mathrm{~g} \mathrm{~kg}^{-1}$ soil) as subplots, and two MLE levels ( $0 \%$ and $3 \%)$ as sub-subplots.

TABLE 1. Some physical and chemical properties of the investigated soil.

\begin{tabular}{|c|c|c|c|c|}
\hline Soil salinity & & S1 & S2 & S3 \\
\hline \multirow{4}{*}{$\begin{array}{l}\text { Soil particles } \\
\text { distribution }\end{array}$} & Sand $\%$ & 41.52 & 46.57 & 45.36 \\
\hline & Silt \% & 37.42 & 29.56 & 29.13 \\
\hline & Clay \% & 21.06 & 23.87 & 24.51 \\
\hline & Textural class & Loam & Loam & Loam \\
\hline \multirow{4}{*}{$\begin{array}{l}\text { Cations** } \\
\left(\text { mmolc L }{ }^{-1}\right)\end{array}$} & $\mathrm{Ca}^{++}$ & 8.54 & 17.09 & 46.56 \\
\hline & $\mathrm{Mg}^{++}$ & 9.51 & 19.95 & 37.35 \\
\hline & $\mathrm{Na}^{+}$ & 6.98 & 17.27 & 18.37 \\
\hline & $\mathrm{K}^{+}$ & 5.12 & 6.95 & 21.12 \\
\hline \multirow{4}{*}{$\begin{array}{l}\text { Anions** } \\
\left(\mathrm{mmol}_{\mathrm{c}} \mathrm{L}^{-1}\right)\end{array}$} & $\mathrm{CO}_{3}^{-}$ & - & - & - \\
\hline & $\mathrm{HCO}_{3}^{-}$ & 7.82 & 20.38 & 37.75 \\
\hline & $\mathrm{Cl}^{-}$ & 12.43 & 32.74 & 33.21 \\
\hline & $\mathrm{SO}_{4}^{--}$ & 9.69 & 8.13 & 36.27 \\
\hline $\mathrm{EC}^{* *}\left(\mathrm{dSm}^{-1}\right)$ & & 3.01 & 6.12 & 12.33 \\
\hline $\mathrm{pH}^{*}$ & & 7.89 & 7.83 & 8.02 \\
\hline Organic matter & & 6.42 & 7.41 & 8.63 \\
\hline $\mathrm{CaCO}_{3}\left(\mathrm{~g} \mathrm{~kg}^{-1}\right)$ & & 55.32 & 61.35 & 62.71 \\
\hline $\mathrm{FC}(\%)$ & & 13.54 & 16.65 & 14.97 \\
\hline \multirow{3}{*}{$\begin{array}{l}\text { Available nutrient } \\
\left(\mathrm{mg} \mathrm{kg}^{-1} \text { soil }\right)\end{array}$} & $\mathrm{N}$ & 60.42 & 58.42 & 49.5 \\
\hline & $\mathrm{P}$ & 10.95 & 8.6 & 6.8 \\
\hline & $\mathrm{K}$ & 88.94 & 99 & 123 \\
\hline
\end{tabular}

*: Soil paste; **: Soil paste extract; FC: Field capacity.

TABLE 2. Chemical composition of Moringa oleifera leaves (on basis of dry weight; DW).

\begin{tabular}{lcc}
\hline Component & Unit & Value \\
\hline Protein & & 273 \\
Phosphorus (P) & & 3.9 \\
Potassium (K) & $\mathrm{g} \mathrm{kg}^{-1} \mathrm{DW}$ & 21.7 \\
Calcium (Ca) & & 24.0 \\
Magnesium (Mg) & & 4.5 \\
Iron (Fe) & & 0.6 \\
\hline Vitamin A ( $\beta$-carotene) & & 163 \\
Vitamin B1(thiamine) & $\mathrm{mg} \mathrm{kg}^{-1} \mathrm{DW}$ & 26 \\
Vitamin B2 (riboflavin) & & 210 \\
Vitamin B3(nicotinic acid) & & 800 \\
Vitamin C (ascorbic acid) & & 1700 \\
Vitamin E (tochopherol acetate) & & 1130 \\
\hline
\end{tabular}


A random sample of three different cuts were taken from each treatment during the two growing seasons to record plant vegetative criteria, some physiological and biochemical properties of Sudan grass plants.

\section{Plant vegetative criteria}

Plant height $(\mathrm{cm})$, fresh and dry weight of shoot systems (g) was determined. Plant samples were dried using an electric oven with drift fan at $70^{\circ} \mathrm{C}$ for $48 \mathrm{~h}$. till a constant weight was reached.

\section{Physiological properties \\ Photosynthetic pigments}

The photosynthetic pigments (chlorophyll $a$, $b$ and carotenoids) were extracted from fresh leaf sample by pure acetone according to Fadeel's method (Fadeels, 1962). The pigments (as mg/g fresh weight) were calculated using the formula adapted by Von Wettestein (1957) as follows:-

Chl. $a=\left(9.784 \times \mathrm{E}_{662}\right)-\left(0.99 \times \mathrm{E}_{644}\right)(\mathrm{mg} / \mathrm{liter})$.

Chl. $b=\left(21.426 \times \mathrm{E}_{644}\right)-\left(4.65 \times \mathrm{E}_{662}\right)(\mathrm{mg} / \mathrm{liter})$.

Carot. $=\left(4.695 \times \mathrm{E}_{440.5}\right)-(0.268 \times \mathrm{Chl} . a+\mathrm{Chl}$. b) $(\mathrm{mg} / \mathrm{liter})$.

where: $\mathrm{E}$ is the reading of the optical density at given wave length. The concentrations of pigments were then expressed in $\mathrm{mg} / \mathrm{g}$ fresh weight of leaves.

\section{Photochemical activity}

Photochemical activity in fresh leaves of Sudan grass plants were determined according to Jagendorf (1956) and modified by Avron (1960) using Ferricyanide. About $0.2 \mathrm{~g}$ of fresh leaf tissues was grind with $1.5 \mathrm{ml}$ phosphate buffer ( $\mathrm{pH} 7.5$ ) and then transferred to conical flasks.

Two $\mathrm{ml}$ of homogenate leaf tissues were transferred to a small beaker and $0.5 \mathrm{ml}$ of Ferricyanide was added and exposed to light for $10 \mathrm{~min}$, then centrifuged at $30004000 \mathrm{xg}$ for $10 \mathrm{~min}$. The optical density of supernatant was determined spectrophotometrically at $420 \mathrm{~nm}$. At the same time, the optical density of supernatant resulted from exposure the suspention to dark for 10min was also spectrophotometrically determined. Chlorophylls concentration was also determined spectrophotometrically at $652 \mathrm{~nm}$. The photochemical activity was estimated as $\mathrm{mM} / \mathrm{gm} \mathrm{Chl}$.

\section{Catalase and peroxidase activities}

Catalase activity: The method described by Feinstien (1949) was used for determining catalase activity as follows:

Second fresh leaf tissue $2.5 \mathrm{~g}$ was ground with purified sand in a cooled mortar and $25 \mathrm{ml}$ of phosphate buffer $\mathrm{pH} 6.8$ was added during grinding. The homogenate was filtered through cotton wool. One $\mathrm{ml}$ of enzyme extract was placed in a conical flask containing $8 \mathrm{ml}$ sodium perborate $1.5 \%$ and $1.5 \mathrm{ml}$ phosphate buffer $\mathrm{pH}$ 6.8. The mixture was incubated at $37^{\circ} \mathrm{C}$ for $5 \mathrm{~min}$ after which the reaction was stopped by adding $10 \mathrm{ml} \mathrm{H}_{2} \mathrm{SO}_{4} 2 \mathrm{~N}$. One drop of manganese chloride $1 \%$ was added for each flask and titration was carried out by means of potassium permanganate $0.05 \mathrm{~N}$ using appropriate plank for each series.

Peroxidase activity: This determination was carried out following the method described by Purr (1950). Second fresh leaf tissue $2.5 \mathrm{~g}$ was placed in a cooled mortar and carefully ground with purified sand, then transferred to a conical flask with the aid of $25 \mathrm{ml}$ distilled water (through a filtered cotton wool was squeezed after filtration). The assay mixture was composed of the following components, i.e., $10 \mathrm{ml}$ phosphate buffer $\mathrm{pH} 5,4 \mathrm{ml}$ ascorbic acid solution $0.44 \%$, $1 \mathrm{ml}$ orthotalidine alcohol solution $0.5 \%, 4 \mathrm{ml}$ hydrogen peroxide solution $30 \%$. The mixture was up to $50 \mathrm{ml}$ with distilled water. Incubation was performed at $25^{\circ} \mathrm{C}$ for $10 \mathrm{~min}$, after which $10 \mathrm{ml}$ of each sample was pipette on to $2.5 \mathrm{ml} 2 \mathrm{~N}$ $\mathrm{H}_{2} \mathrm{SO}_{4}$ in a conical flask .

One drop of starch indicator, the incubated extract was titrated against appropriate blanks with N/250 iodine solution until blue color was formed and persisted for $30 \mathrm{sec}$.

The activity was calculated as $\mathrm{ml} \mathrm{N} / 250$ iodine consumed by gram dray matter of each sample.

\section{Nucleic acids estimation}

Bluck RNA (mainly cytoplasmic RNA) contents were estimated in fresh leaves of sudan grass plants.

The extraction procedure was essentially that of Nitsan \& Long (1966) which was modified by Sharaky (1982) operations up to ethanol/each was carried out at $4^{\circ} \mathrm{C}$. Half gram of leaf tissue 
was homogenized with $4 \mathrm{ml}$ of $0.15 \mathrm{~m} \mathrm{NaCl} 0.1 \mu$ EDTA (Ethylendiamine tetra acetic acid) buffer solution $\mathrm{pH} 8.0$ by a mortar and pestle. An equal volume of $4 \%(\mathrm{w} / \mathrm{v})$ trichloroacetic acid was added immediately to tissue homogenate. After standing the mixture for $3 \mathrm{~h}$ at $-5^{\circ} \mathrm{C}$, the precipitate was extracted successively with methanol (twice), ethanol (twice), boiling ethanol/either (3:1) for 3 min at $60-70^{\circ} \mathrm{C}$ (twice) and either (once). The air dried residue was extracted with $3 \mathrm{ml}$ of $0 . \mathrm{N} \mathrm{KOH}$ at $30^{\circ} \mathrm{C} / 20 \mathrm{~h}$ (alkaline extraction of nucleic acid).

Nucleic acid (RNA and DNA) were recovered by centrifugation after extraction $(5000 \mathrm{rpm} / \mathrm{min})$ about half hour. The supernatant which contains nucleic acid was collected. The precipitate was once more rinsed with $3 \mathrm{ml}$ of $0.3 \mathrm{~N} \mathrm{KOH}$ then centrifuged and supernatant was collected. The two supernatant were combined. Mixed and acidified with $10 \%$ perchloric acid to $\mathrm{pH} 1-2$. After standing the acidified nucleic acid mixture for $6 \mathrm{~h} /-10^{\circ} \mathrm{C}$, it was centrifuged $(5000 \mathrm{rpm} /$ $\min$ ) about half hour to precipitate DNA protein complex. The supernatant which contains RNA as free polyriboncleotides was collected while the DNA protein complex precipitate was once again washed with prechloric acid 5\% and centrifuged. The two supernatant were mixed and made up to acertain volume by prechloric acid 5\%. The quantity ( $\mathrm{mg} / \mathrm{g}$ fresh weight) of RNA and DNA were estimated according to the equations of Nieman \& Poulesn (1967).

\section{Carbohydrate farctions}

Total carbohydrate and total sugar were determined in the dried samples of shoots photometrically according to Bernfeld (1955) and Miller (1959) methods with some modifications.

\section{Color reagent preparation}

One gram of 3,5 dinitro salicylic acid was dissolved in $20 \mathrm{ml}$ of $2 \mathrm{~N} \mathrm{NaOH}$, then $50 \mathrm{ml}$ distilled water and $30 \mathrm{gm}$ of Rochelle salt were added and the mixture was shaken well until dissolving the salt, then the volume was made up to $100 \mathrm{ml}$ with distilled water.

\section{Total carbohydrate}

One tenth gram of dry shoot and grains of Sudan grass powder with $20 \mathrm{ml}$ of $6 \mathrm{~N} \mathrm{HCl}$ were taken in a carbohydrate tube, then the samples were heated for $6 \mathrm{~h}$ in a boiling water bath then filtered using whatman paper No.1.
Twenty $\mathrm{ml}$ of $6 \mathrm{~N} \mathrm{NaOH}$ were added to the filtrate for neutralization, then made up to $100 \mathrm{ml}$ with distilled water. Five $\mathrm{ml}$ from the filtrate were added to $2 \mathrm{ml}$ of color reagent in a test tube, shaked well and heated exactly for $10 \mathrm{~min}$ in a boiling water bath then cooled under running tap water. The color intensities were measured colorimetrically at $550 \mathrm{~nm}$ using spectronic- 20 spectrophotometer.

\section{Total sugars}

From the filtrate of the above mentioned reducing sugars, $10 \mathrm{ml}$ were taken in a carbohydrate tube, $5 \mathrm{ml} 6 \mathrm{~N} \mathrm{HCl}$ were added and incubated for $2 \mathrm{~h}$ in water bath. After incubation, $5 \mathrm{ml}$ of $6 \mathrm{~N} \mathrm{NaOH}$ were added for neutralization and $2 \mathrm{ml}$ of the color reagent were mixed as previously mentioned in case of total carbohydrate.

\section{Statistical analysis}

Data of the current study were subjected to an analysis of variance for a split-split plot design, after testing for the homogeneity of error variances. Statistically significant differences between means were compared at $\mathrm{P} \leq 0.05$ using Duncan's multiple range test. The statistical analysis was carried out using COSTAT computer software (CoHort Software version 6.303, Berkeley, CA, USA).

\section{Results and Discussion}

\section{Plant vegetative characters}

Data present in Table 3 showed the effect of humus component, foliar application of MLE, soil salinity and their interaction on plant height, fresh weight (FW) and dry weight (DW) of Sudan grass plants. Data revealed that plant height, $\mathrm{FW}$ and DW of Sudan grass plants were decreased significantly with increasing soil salinity levels. This trend was found true under different humus component with Moringa leaf extract at all three cuts. In control treatment, the plants in thethird cut were due to high salinity level $\left(12.33 \mathrm{dSm}^{-1}\right)$. Soil salinity reduced plant growth, i.e., plant height may be due to reduction in cell division or cell elongation in both case and/or reduction could raise from toxic effect of ions $(\mathrm{Na}$ and $\mathrm{Cl}$ ) on metabolism or from adverse water relation (Hawker \& Walker, 1978 and Zhaoliang et al., 1995). Similar results were found by Elgharably (2008) who found that total dry mater of wheat plants was significantly decreased by salinity levels. 
TABLE 3. Integrative effect of humus substance and Moringa extract on plant height $(\mathrm{cm})$, fresh and dry weight $\left(\mathrm{g} \mathrm{pot}^{-1}\right)$ of sorghum plants grown under salt stress conditions (Average of two growing seasons 2014 and 2015).

\begin{tabular}{|c|c|c|c|c|c|c|c|c|c|c|c|}
\hline \multirow{2}{*}{$\begin{array}{l}\text { Salinity } \\
\text { level }\end{array}$} & \multirow{2}{*}{$\begin{array}{l}\text { Humus } \\
\text { materials }\end{array}$} & \multirow{2}{*}{$\begin{array}{c}\text { Moringa } \\
\text { extract }\end{array}$} & \multicolumn{3}{|c|}{ Plant height } & \multicolumn{3}{|c|}{ Fresh weight } & \multicolumn{3}{|c|}{ Dry weight } \\
\hline & & & $\begin{array}{l}1^{\text {st }} \\
\text { cut }\end{array}$ & $\begin{array}{l}2^{\text {nd }} \\
\text { cut }\end{array}$ & $\begin{array}{l}3^{\text {rd }} \\
\text { cut }\end{array}$ & $\begin{array}{l}1^{\text {st }} \\
\text { cut }\end{array}$ & $\begin{array}{l}2^{\text {nd }} \\
\text { cut }\end{array}$ & $\begin{array}{l}3^{\text {rd }} \\
\text { cut }\end{array}$ & $\begin{array}{l}1^{\text {st }} \\
\text { cut }\end{array}$ & $\begin{array}{l}2^{\text {nd }} \\
\text { cut }\end{array}$ & $\begin{array}{l}3^{\text {rd }} \\
\text { cut }\end{array}$ \\
\hline \multirow{9}{*}{ S1 } & \multirow{2}{*}{ Without } & Without & 141 & 124 & 72 & 584 & 527 & 401 & 97 & 92 & 67 \\
\hline & & With & 150 & 133 & 73 & 585 & 551 & 422 & 98 & 95 & 70 \\
\hline & \multirow{2}{*}{ HA } & Without & 154 & 151 & 75 & 603 & 580 & 426 & 101 & 95 & 71 \\
\hline & & With & 168 & 158 & 89 & 610 & 582 & 439 & 102 & 97 & 73 \\
\hline & \multirow{2}{*}{ FA } & Without & 152 & 137 & 72 & 591 & 566 & 415 & 99 & 94 & 69 \\
\hline & & With & 168 & 141 & 79 & 601 & 572 & 429 & 100 & 97 & 71 \\
\hline & \multirow{2}{*}{$\mathrm{HA}+\mathrm{FA}$} & Without & 160 & 155 & 87 & 607 & 581 & 433 & 101 & 97 & 72 \\
\hline & & With & 171 & 161 & 93 & 621 & 599 & 450 & 103 & 100 & 75 \\
\hline & \multicolumn{2}{|c|}{ Mean } & 158 & 145 & 80 & 600 & 570 & 427 & 100 & 96 & 71 \\
\hline \multirow{9}{*}{$\mathrm{S} 2$} & \multirow{2}{*}{ Without } & Without & 103 & 86 & 44 & 552 & 510 & 335 & 92 & 85 & 56 \\
\hline & & With & 110 & 92 & 52 & 563 & 516 & 361 & 94 & 86 & 60 \\
\hline & \multirow{2}{*}{ HA } & Without & 130 & 100 & 57 & 574 & 533 & 362 & 94 & 89 & 60 \\
\hline & & With & 136 & 116 & 66 & 582 & 543 & 383 & 96 & 91 & 64 \\
\hline & \multirow{2}{*}{ FA } & Without & 120 & 90 & 54 & 558 & 527 & 353 & 93 & 88 & 59 \\
\hline & & With & 124 & 96 & 56 & 568 & 530 & 370 & 95 & 88 & 62 \\
\hline & \multirow{2}{*}{$\mathrm{HA}+\mathrm{FA}$} & Without & 129 & 101 & 58 & 578 & 542 & 377 & 96 & 90 & 63 \\
\hline & & With & 140 & 123 & 72 & 656 & 550 & 390 & 97 & 92 & 66 \\
\hline & \multicolumn{2}{|c|}{ Mean } & 124 & 100 & 57 & 579 & 531 & 366 & 95 & 89 & 61 \\
\hline \multirow{9}{*}{$\mathrm{S} 3$} & \multirow{2}{*}{ Without } & Without & 69 & 44 & 0 & 522 & 470 & 0 & 87 & 78 & 0 \\
\hline & & With & 78 & 51 & 0 & 531 & 490 & 0 & 89 & 79 & 0 \\
\hline & \multirow{2}{*}{ HA } & Without & 92 & 55 & 36 & 534 & 482 & 234 & 89 & 82 & 39 \\
\hline & & With & 98 & 71 & 39 & 542 & 502 & 250 & 90 & 84 & 42 \\
\hline & & Without & 80 & 50 & 31 & 526 & 474 & 225 & 88 & 80 & 38 \\
\hline & FA & With & 84 & 60 & 32 & 533 & 494 & 229 & 89 & 82 & 40 \\
\hline & & Without & 96 & 76 & 39 & 539 & 494 & 241 & 90 & 82 & 41 \\
\hline & $\mathrm{HA}+\mathrm{FA}$ & With & 100 & 79 & 42 & 549 & 509 & 259 & 92 & 85 & 43 \\
\hline & & & 87 & 61 & 27 & 534 & 489 & 180 & 89 & 82 & 30 \\
\hline & & Without & 104 & 85 & 39 & 553 & 503 & 245 & 92 & 85 & 41 \\
\hline & Without & With & 113 & 92 & 42 & 560 & 519 & 261 & 93 & 87 & 44 \\
\hline & & Without & 125 & 102 & 56 & 570 & 532 & 340 & 95 & 89 & 57 \\
\hline Mean & HA & With & 134 & 115 & 65 & 578 & 543 & 357 & 96 & 90 & 60 \\
\hline of hums & & Without & 117 & 92 & 52 & 558 & 522 & 331 & 93 & 88 & 55 \\
\hline materials & FA & With & 125 & 99 & 56 & 568 & 532 & 343 & 94 & 89 & 58 \\
\hline & & Without & 128 & 111 & 61 & 574 & 539 & 350 & 96 & 90 & 59 \\
\hline & $\mathrm{HA}+\mathrm{FA}$ & With & 137 & 121 & 69 & 609 & 553 & 366 & 97 & 92 & 62 \\
\hline & Gran & nean & 123 & 102 & 55 & 571 & 530 & 324 & 95 & 89 & 54 \\
\hline & & & 1.5 & 1.2 & 0.7 & 2.3 & 2.0 & 2.1 & 0.4 & 0.3 & 0.4 \\
\hline & & & 1.7 & 1.4 & 0.8 & 2.7 & 2.3 & 2.4 & 0.4 & 0.4 & 0.4 \\
\hline & & & 3.0 & 2.4 & 1.4 & NS & 4.1 & 4.2 & NS & 0.7 & 0.7 \\
\hline $\begin{array}{l}0.050 \\
\text { LSD }\end{array}$ & & & 1.2 & 1.0 & 0.6 & 1.9 & 1.7 & 1.7 & 0.3 & 0.3 & 0.3 \\
\hline $0.05 \%$ & & & NS & 1.7 & 1.0 & 3.3 & 2.9 & 3.0 & 0.5 & 0.5 & 0.5 \\
\hline & & & 2.5 & 1.9 & 1.1 & NS & NS & NS & NS & NS & NS \\
\hline & & & 4.3 & 3.3 & 1.9 & NS & NS & 5.9 & NS & NS & 1.0 \\
\hline
\end{tabular}

HA: Humic acid, FA: Fulvic acid, A: Salinity effects, B: Humus effects, C: Moringa effects.

Individual application of humic acid or in combination with fulvic acid gave the best results of plant height, FW and DW of Sudan grass plants at three cuts under all salinity levels than single fulvic acid application in presence of Moringa extract. Humic acid ameliorate vegetative growth by increasing the availability of nutrients, decreased the harmful effect of salinity, advanced root growth and increased $\mathrm{P}, \mathrm{K}$ of soil (Tattini et al., 1991 and Ulukan, 2008 a). The application of humus materials improved chemical, hydropheysical and biological trait of saline soil. This finding remains in well concurrence with those of Basyouny et al. (2003).

From the obtained results, spraying Moringa extract increased significantly morphological characters as compared to the untreated plants. The highest values of plant height, FW and DW of Sudan grass plants at the three cuts under S1, S2 
and S3 were observed with application of humic acid + fulvic acid under foliar spray of Moringa extract followed by humic acid alone. The lowest values were recorded under control plants in the absence of Moringa extract.

Moringa oleifera is an exceptionally nutritive multipurpose plant developed for new vegetable, domesticated animals grub, green fertilizer, biogas, medication, bio-pesticide and production of seed (Fuglie, 2000). Plant growth enhanced by MLE that is may be due to that Moringa contains many mineral elements (i.e., N, P, K and Ca) and rich by amino acid and zeatien (Makkar \& Becker, 1996 and Basra et al., 2009). Such plant growth promoters impact plant development in a few different ways and furthermore support defense mechanisms of plant against stresses by increasing endogenous concentration of plant growth regulator's (PGR). Also, PGR can used as a foliar spray or seed priming agent. Use of MLE as plant growth increased crop production by $20-35 \%$. Spray influences the harvests by longer life expectancy, heavier roots, stems and leaves, producing large and more fruits and increasing yield production by $20-35 \%$ (Foidle et al., 2001), accelerating growth of young plants and proved to be an ideal plant growth in many experiments (Makkar \& Becker, 1996; Nouman et al., 2013 and Basra et al., 2005).

\section{Physiological and biochemical properties \\ Photosynthetic pigments and photochemical activity}

The obtained results in Tables 4 and 5 illustrated significant variation among salinity stress levels of chlorophyll $a, b$ and carotenoids and photochemical activity of Sudan grass leaves. The results showed that photosynthetic pigments and photochemical activity were decreased by increasing soil salinity levels. This trend was found true under different humus component with or without Moringa leaf extract, at all three cuts. As mention before control plants with the untreated soil due to extremely high salinity $\left(12.33 \mathrm{dSm}^{-1}\right)$ at third cut was died.

The obtained results from the effect of salinity stress on the concentration of photosynthetic pigments and photochemical activity in plant leaves may be substantiated by finding of Horváth et al. (2015) in tomato and Porcela et al. (2015) in rice, indicated that photosynthetic pigments were decreased significantly under high salinity levels. Salinity stress decreased net photosynthetic rate by conductance of stomatal and transpiration (Chen et al., 2014). Decreasing chlorophyll content by salinity stress may be ascribed to increase activity of chlorophyll and degradation chloroplast enzymes (Reddy \& Varo, 1986). The reductory effect of salinity on chlorophyll content might be attributed to its negative action on increase chlorophyllase activity which degradated chlorophyll (Sivtrev et al., 1973).

In this regard Yeo \& Flovers (1983) and Malibari et al. (1993) reported that the reduction of chlorophyll content under salinity stress may be due to the inhibition effect of the accumulation ions of various salts on biosynthesis of different pigment fraction.

Data indicated that application humus component, i.e., humic acid and fulvic acid under salinity stress condition (S1, S2 and S3) showed significant differences in chlorophyll $a, b$ and carotenoids as well as photochemical activity. Generally humic acid was more effective than fulvic acid in increasing photosynthetic pigments and photochemical activity. Similarly, (Hanafy et al., 2010) indicated that addition of humic acid significantly increased photosynthetic pigments concentration under calcareous soils conditions. Also, Fu et al. (1994) revealed that application of FA to rape plants increased chlorophyll content and intensity of photosynthesis. Increasing leaves chlorophyll content by application of HA might be attributed to accumulation of nutrient which enhancing photosynthesis.

Foliar application of MLE caused positive effect on photosynthetic pigments and photochemical activity of plant under salinity levels. The highest values of photosynthetic pigments and photochemical activity were obtained by mixed application of HA + FA under spray Moringa leaf extract, while, the lowest one was obtained in plants not receiving humus component as well as Moringa extract. Moringa leaves have been accounted for to be a rich wellspring of an important component (i.e., amino acid, zeatien, $\beta$-carotene, $\mathrm{N}, \mathrm{P}, \mathrm{K}$ and $\mathrm{Ca}$ ) and act as a good source of some antioxidants (i.e., flavonoid, phenolic components and ascorbic acid) (Dillard \& German, 2000 and Siddhuraju $\&$ Becker, 2003). So, the exogenous applications of Moringa leaf extract (MLE) improve the antioxidants which ameliorate the bad affect of salinity and increase photosynthetic pigments and photochemical activity as compared to the untreated one (control). 
TABLE 4. Integrative effect of humus substance and Moringa extract on leaf photosynthetic pigments (mg/g FW) of sorghum plants grown under salt stress conditions (Average of two growing seasons 2014 and 2015).

\begin{tabular}{|c|c|c|c|c|c|c|c|c|c|c|c|}
\hline \multirow{2}{*}{$\begin{array}{l}\text { Salinity } \\
\text { level }\end{array}$} & \multirow{2}{*}{$\begin{array}{c}\text { Humus } \\
\text { materials }\end{array}$} & \multirow{2}{*}{$\begin{array}{c}\text { Moringa } \\
\text { extract }\end{array}$} & \multicolumn{3}{|c|}{ Chlorophyll $a$} & \multicolumn{3}{|c|}{ Chlorophyll $\boldsymbol{b}$} & \multicolumn{3}{|c|}{ Carotoniods } \\
\hline & & & $1^{\text {st }}$ cut & $2^{\text {nd }}$ cut & $3^{\text {rd }}$ cut & $1^{\text {st }}$ cut & $2^{\text {nd }}$ cut & $3^{\text {rd }}$ cut & $1^{\text {st }}$ cut & $2^{\text {nd }}$ cut & $3^{\text {rd }}$ cut \\
\hline \multirow{9}{*}{$\mathrm{S} 1$} & \multirow{2}{*}{ Without } & Without & 1.19 & 1.02 & 0.76 & 0.46 & 0.35 & 0.26 & 1.06 & 1.10 & 0.51 \\
\hline & & With & 1.19 & 1.07 & 0.79 & 0.52 & 0.38 & 0.29 & 1.10 & 1.11 & 0.55 \\
\hline & \multirow{2}{*}{ HA } & Without & 1.24 & 1.19 & 0.84 & 0.57 & 0.42 & 0.36 & 1.14 & 1.12 & 0.61 \\
\hline & & With & 1.38 & 1.22 & 0.89 & 0.63 & 0.48 & 0.39 & 1.19 & 1.14 & 0.63 \\
\hline & \multirow{2}{*}{ FA } & Without & 1.20 & 1.17 & 0.80 & 0.55 & 0.36 & 0.30 & 1.10 & 1.11 & 0.58 \\
\hline & & With & 1.23 & 1.18 & 0.83 & 0.56 & 0.38 & 0.31 & 1.15 & 1.13 & 0.61 \\
\hline & \multirow{2}{*}{$\mathrm{HA}+\mathrm{FA}$} & Without & 1.30 & 1.19 & 0.87 & 0.58 & 0.44 & 0.37 & 1.15 & 1.12 & 0.62 \\
\hline & & With & 1.42 & 1.31 & 0.91 & 0.75 & 0.49 & 0.40 & 1.27 & 1.22 & 0.66 \\
\hline & \multicolumn{2}{|c|}{ Mean } & 1.27 & 1.17 & 0.84 & 0.58 & 0.41 & 0.34 & 1.15 & 1.13 & 0.60 \\
\hline \multirow{9}{*}{$\mathrm{S} 2$} & \multirow{2}{*}{ Without } & Without & 0.99 & 0.98 & 0.69 & 0.35 & 0.26 & 0.14 & 1.00 & 0.99 & 0.46 \\
\hline & & With & 1.00 & 1.00 & 0.72 & 0.39 & 0.29 & 0.22 & 1.06 & 1.01 & 0.56 \\
\hline & \multirow{2}{*}{ HA } & Without & 1.15 & 1.06 & 0.74 & 0.53 & 0.30 & 0.19 & 1.04 & 1.01 & 0.49 \\
\hline & & With & 1.18 & 1.17 & 0.77 & 0.55 & 0.34 & 0.25 & 1.08 & 1.04 & 0.60 \\
\hline & \multirow{2}{*}{ FA } & Without & 1.11 & 1.00 & 0.71 & 0.41 & 0.29 & 0.15 & 1.02 & 1.00 & 0.47 \\
\hline & & With & 1.14 & 1.04 & 0.75 & 0.44 & 0.30 & 0.25 & 1.07 & 1.04 & 0.56 \\
\hline & \multirow{2}{*}{$\mathrm{HA}+\mathrm{FA}$} & Without & 1.16 & 1.10 & 0.77 & 0.54 & 0.31 & 0.21 & 1.05 & 1.03 & 0.50 \\
\hline & & With & 1.21 & 1.18 & 0.79 & 0.55 & 0.36 & 0.29 & 1.09 & 1.05 & 0.60 \\
\hline & \multicolumn{2}{|c|}{ Mean } & 1.11 & 1.07 & 0.74 & 0.47 & 0.31 & 0.21 & 1.05 & 1.02 & 0.53 \\
\hline \multirow{9}{*}{ S3 } & \multirow{2}{*}{ Without } & Without & 0.98 & 0.84 & 0 & 0.29 & 0.11 & 0 & 0.84 & 0.71 & 0 \\
\hline & & With & 0.99 & 0.89 & 0 & 0.30 & 0.13 & 0 & 0.91 & 0.74 & 0 \\
\hline & \multirow{2}{*}{ HA } & Without & 1.06 & 0.96 & 0.67 & 0.45 & 0.19 & 0.11 & 0.91 & 0.86 & 0.42 \\
\hline & & With & 1.07 & 0.99 & 0.69 & 0.48 & 0.23 & 0.20 & 0.99 & 0.90 & 0.54 \\
\hline & FA & Without & 1.04 & 0.89 & 0.62 & 0.32 & 0.17 & 0.11 & 0.98 & 0.79 & 0.41 \\
\hline & $1 \mathrm{~A}$ & With & 1.06 & 0.94 & 0.64 & 0.35 & 0.18 & 0.18 & 0.98 & 0.81 & 0.51 \\
\hline & & Without & 1.07 & 0.96 & 0.67 & 0.45 & 0.21 & 0.14 & 0.99 & 0.86 & 0.46 \\
\hline & - & With & 1.10 & 1.03 & 0.70 & 0.51 & 0.26 & 0.20 & 0.99 & 0.99 & 0.56 \\
\hline & & & 1.05 & 0.94 & 0.50 & 0.39 & 0.19 & 0.12 & 0.95 & 0.83 & 0.36 \\
\hline & & Without & 1.05 & 0.95 & 0.48 & 0.37 & 0.24 & 0.13 & 0.97 & 0.93 & 0.32 \\
\hline & Without & With & 1.06 & 0.99 & 0.50 & 0.40 & 0.27 & 0.17 & 1.02 & 0.95 & 0.37 \\
\hline & $\mathrm{HA}$ & Without & 1.15 & 1.07 & 0.75 & 0.52 & 0.30 & 0.22 & 1.03 & 1.00 & 0.51 \\
\hline Mean & 111 & With & 1.21 & 1.12 & 0.78 & 0.55 & 0.35 & 0.27 & 1.08 & 1.02 & 0.59 \\
\hline of hums & FA & Without & 1.12 & 1.02 & 0.71 & 0.43 & 0.27 & 0.19 & 1.03 & 0.97 & 0.49 \\
\hline materials & $1 \pi$ & With & 1.14 & 1.05 & 0.74 & 0.45 & 0.29 & 0.25 & 1.07 & 0.99 & 0.56 \\
\hline & $\mathrm{HA}+\mathrm{FA}$ & Without & 1.18 & 1.09 & 0.77 & 0.52 & 0.32 & 0.25 & 1.07 & 1.01 & 0.53 \\
\hline & ПАТГА & With & 1.24 & 1.17 & 0.80 & 0.60 & 0.37 & 0.30 & 1.12 & 1.09 & 0.61 \\
\hline & Granc & Mean & 1.14 & 1.06 & 0.69 & 0.48 & 0.30 & 0.22 & 1.05 & 1.00 & 0.50 \\
\hline & & & 0.08 & 0.06 & 0.06 & 0.01 & 0.05 & 0.04 & 0.05 & 0.04 & 0.02 \\
\hline & & & NS & 0.07 & 0.07 & 0.01 & 0.06 & 0.05 & NS & 0.04 & 0.03 \\
\hline & & & NS & NS & 0.11 & 0.01 & NS & NS & NS & 0.07 & 0.05 \\
\hline LSD $0.05 \%$ & & & NS & 0.05 & NS & 0.01 & NS & 0.03 & NS & NS & 0.02 \\
\hline & & & NS & NS & NS & 0.01 & NS & NS & NS & 0.03 & NS \\
\hline & & & 0.13 & NS & NS & 0.01 & 0.08 & NS & NS & NS & NS \\
\hline & & & NS & NS & 0.16 & 0.01 & 0.14 & NS & NS & NS & NS \\
\hline
\end{tabular}

HA: Humic acid, FA: Fulvic acid, A: Salinity effects, B: Humus effects, C: Moringa effects. 
TABLE 5. Integrative effect of humus substance and Moringa extract on photochemical activity ( $\mu \mathrm{mol} / \mathrm{mg}$ Chl./min), peroxidase (POX) $\left(\mu \mathrm{mol} \mathrm{H}_{2} \mathrm{O}_{2} / \mathrm{mg} \mathrm{FW} / \mathrm{min}\right)$ and catalase $(\mathrm{CAT})\left(\mu \mathrm{mol} \mathrm{H}_{2} \mathrm{O}_{2} / \mathrm{mg} \mathrm{FW} / \mathrm{min}\right)$ activities in sorghum plants grown under salt stress conditions.

\begin{tabular}{|c|c|c|c|c|c|c|c|c|c|c|c|}
\hline \multirow{2}{*}{$\begin{array}{l}\text { Salinity } \\
\text { level }\end{array}$} & \multirow{2}{*}{$\begin{array}{l}\text { Humus } \\
\text { materials }\end{array}$} & \multirow{2}{*}{$\begin{array}{c}\text { Moringa } \\
\text { extract }\end{array}$} & \multicolumn{3}{|c|}{ Photochemical activity } & \multicolumn{3}{|c|}{ POX activity } & \multicolumn{3}{|c|}{ CAT activity } \\
\hline & & & $1^{\text {st }}$ cut & $2^{\text {nd }}$ cut & $3^{\text {rd }}$ cut & $1^{\text {st }}$ cut & $2^{\text {nd }}$ cut & $3^{\text {rd }}$ cut & $1^{\text {st }}$ cut & $2^{\text {nd }}$ cut & $3^{\text {rd }}$ cut \\
\hline \multirow{9}{*}{ S1 } & \multirow{2}{*}{ Without } & Without & 48.4 & 36.2 & 34.2 & 3.41 & 2.76 & 2.61 & 310 & 249 & 143 \\
\hline & & With & 50.1 & 37.1 & 36.2 & 3.68 & 2.96 & 3.01 & 329 & 263 & 171 \\
\hline & \multirow{2}{*}{ HA } & Without & 55.3 & 40.3 & 39.7 & 3.84 & 3.03 & 3.01 & 331 & 255 & 151 \\
\hline & & With & 56.4 & 42.3 & 40.2 & 4.11 & 3.51 & 3.76 & 356 & 282 & 191 \\
\hline & \multirow{2}{*}{ FA } & Without & 49.0 & 39.8 & 38.7 & 3.68 & 2.81 & 2.96 & 326 & 251 & 146 \\
\hline & & With & 52.1 & 39.9 & 38.8 & 3.91 & 3.06 & 3.19 & 331 & 277 & 182 \\
\hline & \multirow{2}{*}{$\mathrm{HA}+\mathrm{FA}$} & Without & 50.2 & 40.7 & 40.0 & 3.96 & 3.12 & 3.19 & 338 & 263 & 159 \\
\hline & & With & 58.9 & 44.7 & 44.1 & 4.16 & 3.69 & 3.96 & 362 & 291 & 198 \\
\hline & \multicolumn{2}{|c|}{ Mean } & 52.5 & 40.1 & 39.0 & 3.84 & 3.12 & 3.21 & 335 & 266 & 168 \\
\hline \multirow{9}{*}{ S2 } & \multirow{2}{*}{ Without } & Without & 39.1 & 29.6 & 26.3 & 3.62 & 3.48 & 3.31 & 463 & 341 & 255 \\
\hline & & With & 40.4 & 30.0 & 28.0 & 3.92 & 3.81 & 3.62 & 488 & 366 & 269 \\
\hline & \multirow{2}{*}{ HA } & Without & 41.1 & 32.8 & 30.4 & 3.82 & 3.96 & 3.81 & 471 & 368 & 270 \\
\hline & & With & 45.2 & 35.0 & 34.3 & 4.30 & 4.10 & 4.15 & 501 & 388 & 280 \\
\hline & \multirow{2}{*}{ FA } & Without & 39.8 & 31.3 & 29.8 & 3.77 & 3.76 & 3.59 & 467 & 352 & 261 \\
\hline & & With & 40.3 & 31.3 & 30.2 & 3.96 & 3.98 & 3.89 & 492 & 375 & 275 \\
\hline & \multirow{2}{*}{$\mathrm{HA}+\mathrm{FA}$} & Without & 42.7 & 33.1 & 31.1 & 3.91 & 4.01 & 4.09 & 489 & 373 & 273 \\
\hline & & With & 46.2 & 37.0 & 35.7 & 4.38 & 4.19 & 4.69 & 503 & 392 & 281 \\
\hline & \multicolumn{2}{|c|}{ Mean } & 41.8 & 32.5 & 30.7 & 3.96 & 3.91 & 3.89 & 484 & 369 & 271 \\
\hline \multirow{9}{*}{ S3 } & \multirow{2}{*}{ Without } & Without & 31.3 & 20.2 & 0 & 4.81 & 4.02 & 0 & 569 & 418 & 0 \\
\hline & & With & 31.9 & 21.2 & 0 & 4.99 & 4.56 & 0 & 591 & 439 & 0 \\
\hline & \multirow{2}{*}{ HA } & Without & 36.8 & 23.9 & 20.4 & 5.03 & 4.76 & 4.46 & 582 & 440 & 242 \\
\hline & & With & 37.3 & 25.1 & 21.9 & 5.62 & 4.98 & 4.72 & 611 & 461 & 263 \\
\hline & FA & Without & 33.2 & 21.9 & 19.0 & 4.93 & 4.19 & 3.96 & 576 & 421 & 331 \\
\hline & FA & With & 35.3 & 22.3 & 19.9 & 5.11 & 4.79 & 4.13 & 581 & 448 & 348 \\
\hline & $\mathrm{H} \Delta+\mathrm{F} \Delta$ & Without & 36.8 & 24.1 & 21.2 & 5.15 & 4.82 & 4.69 & 593 & 446 & 353 \\
\hline & ПАТГА & With & 40.0 & 27.0 & 23.9 & 5.83 & 5.19 & 4.81 & 623 & 468 & 375 \\
\hline & & & 35.3 & 23.2 & 20.3 & 5.18 & 4.66 & 3.35 & 591 & 443 & 239 \\
\hline & Without & Without & 39.6 & 28.7 & 20.2 & 3.95 & 3.42 & 1.97 & 447 & 336 & 133 \\
\hline & Witnoul & With & 40.8 & 29.4 & 21.4 & 4.20 & 3.78 & 2.21 & 469 & 356 & 147 \\
\hline & & Without & 44.4 & 32.3 & 30.1 & 4.23 & 3.92 & 3.76 & 461 & 354 & 221 \\
\hline Mean & HA & With & 47.3 & 34.1 & 32.1 & 4.68 & 4.20 & 4.21 & 489 & 377 & 245 \\
\hline of hums & FA & Without & 40.7 & 31.0 & 29.2 & 4.13 & 3.59 & 3.50 & 456 & 341 & 246 \\
\hline materials & FA & With & 42.6 & 31.2 & 29.6 & 4.33 & 3.94 & 3.74 & 468 & 367 & 268 \\
\hline & $H \Delta+F \Delta$ & Without & 43.2 & 32.6 & 30.8 & 4.34 & 3.98 & 3.99 & 473 & 361 & 262 \\
\hline & TГA & With & 48.4 & 36.3 & 34.6 & 4.79 & 4.36 & 4.49 & 496 & 384 & 285 \\
\hline & Granc & nean & 41.3 & 31.9 & 28.5 & 4.33 & 3.90 & 3.48 & 470 & 359 & 226 \\
\hline & & & 0.27 & 0.29 & 0.21 & 0.27 & 0.23 & 0.24 & 3.3 & 14.0 & 16.5 \\
\hline & & & 0.32 & 0.33 & 0.24 & 0.31 & 0.27 & 0.28 & 3.9 & NS & 19.0 \\
\hline & & & 0.55 & 0.57 & 0.42 & NS & NS & 0.49 & NS & NS & 32.9 \\
\hline LSD $0.05 \%$ & & & 0.22 & 0.23 & 0.17 & 0.22 & 0.19 & 0.20 & 2.7 & 11.4 & 13.4 \\
\hline & & & 0.39 & 0.40 & 0.30 & NS & NS & NS & NS & NS & 23.3 \\
\hline & & & 0.45 & 0.47 & 0.34 & NS & 0.38 & NS & 5.5 & NS & 26.9 \\
\hline & & & 0.77 & 0.81 & 0.59 & NS & NS & NS & 9.4 & NS & 46.5 \\
\hline
\end{tabular}

HA: Humic acid, FA: Fulvic acid, A: Salinity effects, B: Humus effects, C: Moringa effects. 
Peroxidase (POX) and catalase (CAT) activity

From the data in Table 5, it could be clearly noticed that increase soil salinity levels significantly increased activities of POX and CAT of Sudan grass homogenate in the three cuts, the high level salinity stress (S3) was the most effective one increased POX and CAT activity. These results were sustained by Lechno et al. (1997) who found that, $\mathrm{NaCl}$ treatment increased the activities of antioxidants enzymes. Salinity stress cause over production of reactive oxygen species (ROS) in plant tissue (Rady et al., 2015). The antioxidant defense system is essential for reduction oxidative destruction in plants under stress by releasing excessive reactive oxygen species (ROS) (Baloğlu et al., 2012). Increased antioxidative enzyme activities induced by salinity stress protected cell proteins, cell membrane and metabolic mechanism, which keep subcellular structure from damage by salinity stress (Sekmen et al., 2012).

CAT is a main enzyme that eliminates $\mathrm{H}_{2} \mathrm{O}_{2}$ in cell mitochondrion and microbody (Shigeoka et al., 2002). CAT enzyme is an important antioxidant system that catabolizes hydrogen peroxide, a precursor of reactive oxidants and reacts with $\mathrm{H}_{2} \mathrm{O}_{2}$ directly to form water and oxygen (Smironoff, 1993).

Regarding to the effect of application various humus component as well as foliar spray with Moringa leaf extract resulted in a positive significant increase of POX and CAT activities in plant under different levels of salinity stress during three successive cuts. The highest values of POX and CAT were obtained by mixed application of HA + FA with Moringa leaf extract spray under $\mathrm{S} 3\left(12.33 \mathrm{dSm}^{-1}\right)$ salinity level.

However, untreated plants under S1 (3.01 dSm 1) salinity level showed the lowest POX and CAT activities. Exogenous application of HA increased significantly POX and CAT activities with increasing HA levels (Zhang et al., 2013). Humic acid isable to control hormone levels, enhance plant growth and ameliorate stress tolerance (Saruhan et al., 2011). Humic acid regulation mechanism of antioxidative enzyme which mitigating the negative effect of stress (Zhang et al., 2013). Also, FA application substantially ameliorated the adversities of stress by increasing levels of antioxidant enzyme (superoxide dismutase (SOD), POD and CAT activities
(Anjum et al., 2011). While, Moringa leaf extract contains antioxidant including proline and phytohormone such as indol acetic acid (IAA), gibberlline and cytokinin which improve plant growth, metabolism and antioxidant enzymes (Rehman et al., 2014).

\section{Nucleic acids}

Data present in Table 6 showed that the three salinity levels S1, S2 and S3 significantly decreased total DNA and RNA of sudan grass leaves in the three cuts, increasing salinity levels up to $\left(12.33 \mathrm{dSm}^{-1}\right)$ was the most effective. Salinity had been showed to reduce the synthesis of total DNA, RNA and protein in many plants (Levitt, 1980). The decrease of RNA due to salinization may be explained by either a suppression in nutrient absorption as a result of $\mathrm{NaCl}$ or $\mathrm{CaCl}_{2}$ uptake in combination with nutrient ions, or by excess accumulation of certain ion mainly $\mathrm{Cl}^{-}$ in the sweet pepper cells (Al-Bahrany, 1994). Increasing $\mathrm{NaCl}$ from 0.1 to $1.5 \mathrm{mM}$ decreased DND, RNA binding level in cowpea plants (Lee $\&$ Hacker, 2001). These reductions may be due to triggering increase in ribonuclease and protease activities (Galston, 1983).

Data also indicated that, application of different humus component as well as foliar spray with Moringa leaf extract caused positive effect on nucleic acid (RNA \& DNA) of sudan grass plants grown under different levels of soil salinity. The highest values of RNA and DNA under S1, S2 and S3 level revealed 243, 192, 172mg/g FW, respectively for RNA and $18.81,13.61,9.11 \mathrm{mg} / \mathrm{g}$ FW, respectively for DNA were obtained by mixed application with HA+FA under spray with Moringa leaf extract, while, the lowest one was obtained in plants not receiving humus materials as well as Moringa extract.

In this respect humic acid improve plant growth by enhancing nutrient uptake, photosynthesis, including synthesis total RNA \& DNA and proteins as well as plasma membrane stabilization (Cimrin et al., 2010 and Saruhan et al., 2011).

\section{Carbohydrate fractions}

Data in Table 7 revealed that total carbohydrate ant total sugar of Sudan grass shoot were significantly and gradually decreased with increasing salinity levels especially under high salinity level (S3). In this concern, Farouk et al. (2001) stated that artificial salinity stress 
significantly decreased total carbohydrate content of shoots. While, Hajar et al. (1996) on Nigella sativa found that total sugar and starch decreased with increasing $\mathrm{NaCl}$ salinity. The synthesis of carbohydrate was depressed by water stress due to soil salinity (Kilany et al., 2006). Abiotic stress represses cell expansion more than cell division, its diminished plant development by influencing different physiological and biochemical process, for example, ion uptake, nutrient metabolism and carbohydrate (Farooq et al., 2009).

TABLE 6. Integrative effect of humus substance and Moringa extract on the contents of RNA and DNA ( $\mu \mathrm{g} / \mathrm{g}$ FW) of sorghum plants grown under salt stress conditions (Average of two growing seasons 2014 and 2015).

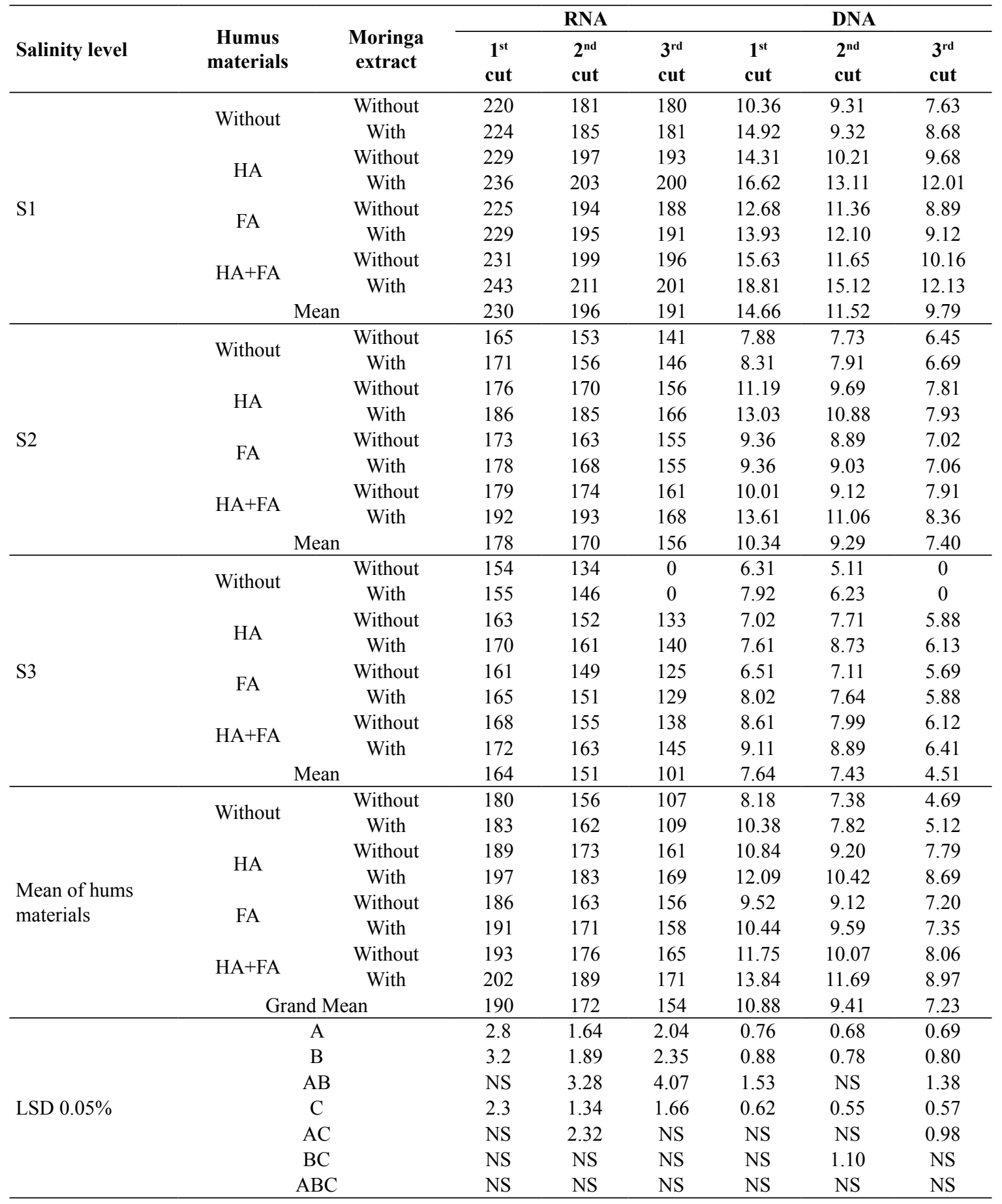

HA: Humic acid, FA: Fulvic acid, A: Salinity effects, B: Humus effects, C: Moringa effects. 
TABLE 7. Integrative effect of humus substance and Moringa extract on the contents of total carbohydrate and total sugar (\%) of sorghum plants grown under salt stress conditions.

\begin{tabular}{|c|c|c|c|c|c|c|c|c|}
\hline \multirow[b]{2}{*}{ Salinity level } & \multirow{2}{*}{$\begin{array}{c}\text { Humus } \\
\text { materials }\end{array}$} & \multirow[b]{2}{*}{$\begin{array}{c}\text { Moringa } \\
\text { extract }\end{array}$} & \multicolumn{3}{|c|}{ Total carbohydrate } & \multicolumn{3}{|c|}{ Total sugar } \\
\hline & & & $\begin{array}{l}1^{\text {st }} \\
\text { cut }\end{array}$ & $\begin{array}{l}2^{\text {nd }} \\
\text { cut }\end{array}$ & $\begin{array}{l}3^{\text {rd }} \\
\text { cut }\end{array}$ & $\begin{array}{l}1^{\text {st }} \\
\text { cut }\end{array}$ & $\begin{array}{l}2^{\text {nd }} \\
\text { cut }\end{array}$ & $\begin{array}{l}3^{\text {rd }} \\
\text { cut }\end{array}$ \\
\hline \multirow{9}{*}{ S1 } & \multirow{2}{*}{ Without } & Without & 30.2 & 28.4 & 25.7 & 7.37 & 6.34 & 6.03 \\
\hline & & With & 32.9 & 30.1 & 26.3 & 7.99 & 6.52 & 6.52 \\
\hline & \multirow{2}{*}{ HA } & Without & 34.8 & 32.7 & 29.4 & 8.78 & 7.52 & 7.11 \\
\hline & & With & 36.2 & 33.4 & 31.2 & 9.11 & 8.13 & 7.77 \\
\hline & \multirow{2}{*}{ FA } & Without & 34.1 & 34.1 & 27.7 & 8.36 & 7.18 & 6.88 \\
\hline & & With & 34.7 & 31.2 & 28.2 & 8.76 & 7.21 & 7.23 \\
\hline & \multirow{2}{*}{$\mathrm{HA}+\mathrm{FA}$} & Without & 35.0 & 31.3 & 30.0 & 8.93 & 7.98 & 7.76 \\
\hline & & With & 37.0 & 34.6 & 31.6 & 9.69 & 8.86 & 8.19 \\
\hline & \multicolumn{2}{|c|}{ Mean } & 34.4 & 32.0 & 28.8 & 8.62 & 7.47 & 7.19 \\
\hline \multirow{9}{*}{$\mathrm{S} 2$} & \multirow{2}{*}{ Without } & Without & 25.3 & 24.6 & 21.3 & 6.81 & 5.13 & 4.83 \\
\hline & & With & 27.6 & 25.0 & 21.9 & 6.98 & 5.42 & 4.92 \\
\hline & \multirow{2}{*}{ HA } & Without & 29.9 & 27.8 & 24.8 & 7.21 & 5.99 & 5.32 \\
\hline & & With & 32.1 & 29.9 & 25.4 & 7.82 & 6.38 & 5.93 \\
\hline & \multirow{2}{*}{ FA } & Without & 28.7 & 27.4 & 23.2 & 7.08 & 5.83 & 5.13 \\
\hline & & With & 28.9 & 27.7 & 23.9 & 7.19 & 5.93 & 5.19 \\
\hline & \multirow{2}{*}{$\mathrm{HA}+\mathrm{FA}$} & Without & 29.8 & 28.2 & 23.9 & 7.53 & 6.11 & 5.87 \\
\hline & & With & 32.8 & 30.0 & 26.3 & 8.13 & 6.92 & 6.06 \\
\hline & \multicolumn{2}{|c|}{ Mean } & 29.4 & 27.6 & 23.9 & 7.34 & 5.96 & 5.41 \\
\hline \multirow{9}{*}{ S3 } & \multirow{2}{*}{ Without } & Without & 21.4 & 19.9 & 0 & 4.26 & 3.98 & 0 \\
\hline & & With & 22.4 & 20.1 & 0 & 4.99 & 4.03 & 0 \\
\hline & \multirow{2}{*}{ HA } & Without & 24.2 & 22.9 & 18.4 & 5.99 & 4.79 & 3.92 \\
\hline & & With & 25.4 & 24.9 & 19.7 & 6.89 & 4.93 & 4.63 \\
\hline & \multirow{2}{*}{ FA } & Without & 23.2 & 22.1 & 17.1 & 5.21 & 4.11 & 3.71 \\
\hline & & With & 24.0 & 22.9 & 19.8 & 5.23 & 4.52 & 4.11 \\
\hline & \multirow{2}{*}{$\mathrm{HA}+\mathrm{FA}$} & Without & 24.8 & 24.2 & 20.7 & 6.63 & 4.88 & 4.63 \\
\hline & & With & 26.7 & 25.6 & 21.3 & 7.78 & 5.26 & 4.98 \\
\hline & & & 24.0 & 22.8 & 14.6 & 5.87 & 4.56 & 3.25 \\
\hline & Without & Without & 25.6 & 24.3 & 15.7 & 6.15 & 5.15 & 3.62 \\
\hline & Without & With & 27.6 & 25.1 & 16.1 & 6.65 & 5.32 & 3.81 \\
\hline & HA & Without & 29.6 & 27.8 & 24.2 & 7.33 & 6.10 & 5.45 \\
\hline & HA & With & 31.3 & 28.6 & 25.4 & 7.94 & 6.48 & 6.11 \\
\hline Mean of hums & FA & Without & 28.7 & 27.9 & 22.7 & 6.88 & 5.71 & 5.24 \\
\hline & FA & With & 29.2 & 27.3 & 24.0 & 7.06 & 5.89 & 5.51 \\
\hline & & Without & 29.9 & 28.7 & 24.9 & 7.70 & 6.32 & 6.09 \\
\hline & HA+FA & With & 32.2 & 30.1 & 26.4 & 8.53 & 7.01 & 6.41 \\
\hline & Gra & ean & 29.3 & 27.5 & 22.4 & 7.28 & 6.00 & 5.28 \\
\hline & & & 0.82 & 0.71 & 0.56 & 0.75 & 0.63 & 0.51 \\
\hline & & & 0.95 & 0.82 & 0.64 & NS & 0.72 & 0.59 \\
\hline & & & NS & NS & 1.12 & NS & NS & 1.02 \\
\hline LSD $0.05 \%$ & & & 0.67 & 0.58 & 0.46 & NS & 0.51 & 0.42 \\
\hline & & & NS & NS & 0.79 & NS & NS & NS \\
\hline & & & NS & NS & NS & NS & 1.02 & NS \\
\hline & & & NS & NS & NS & NS & 1.77 & NS \\
\hline
\end{tabular}

HA: Humic acid, FA: Fulvic acid, A: Salinity effects, B: Humus effects, C: Moringa effects.

Its interest to mention that application of humus materials (HA \& FA) exhibited the highest values of carbohydrate fraction as compared to control. In this respect HA was the more effective than FA. These results hold true at the three cuts.
In all cases, the increase in carbohydrate fraction was over highly significant in comparison with untreated one. These results in agree with Ali et al. (2013) who reported that application of humic acid increased leaves total carbohydrate content 
under salinity stress. Also, humic acid ameliorate physiological process like osmotic adjustment and composition of carbohydrate (Jianguo et al., 1998).

Furthermore, spraying Moringa leaf extract in combination with humus materials were more effective than increasing carbohydrate fraction of Sudan grass plants under other treatments during three cuts under three levels of soil salinity. Increasing carbohydrate fraction reached its maximum values at $\mathrm{HA}+\mathrm{FA}$ under spray Moringa leaf extract.

In this condition, foliar spray of MLE increased total soluble sugar and total carbohydrate (Abdalla, 2013 and Rady et al., 2015). Application of Moringa leaf extract gave chance to great translocation of the nutrient assimilated into healthy cells to be utilized in various metabolic process such as carbohydrate synthesis under saline soil (Semida et al., 2014).

The interaction between humus materials, Moringa leaf extract and soil salinity levels were insignificant variations for carbohydrate fractions.

\section{Conclusion}

Results of this study show that the integrative application of HM (HA+FA) and MLE was effective in alleviating the physiological response of salt stress damages. The beneficial effects of the integrative HM+MLE application were more pronounced under moderate soil salinity $\left(6.12 \mathrm{dS} \mathrm{m}^{-1}\right)$. The integrative $\mathrm{HM}+$ MLE-treated sorghum plants under salt stress maintained higher osmoprotectants, phytohormones, nucleic acids and antioxidants, concluding that this integrative treatment plays a very important role in plant growth, development and metabolism and responses to salt stress. It could also be concluded that HM and MLE can be used as plant bio-stimulants/nutritive means in integration under normal or abnormal conditions as an economic and natural source of mineral nutrients, phytohormones, amino acids, osmoprotectants, and antioxidants. Further studies are required to assess the accurate functions of HM and MLE in signaling pathways and physiological responses to abiotic stresses.

\section{References}

Abdalla, M.M. (2013) The potential of Moringa oleifera extract as a biostimulant in enhancing the growth, biochemical and hormonal contents in rocket (Eruca vesicaria subsp. sativa) plants. Int. J. Plant Physiol. and Biochem. 5(3), 42-49.

Al-Bahrany, A.M. (1994) Influence of salinity on free proline accumulation, total RNA content and some minerals $(\mathrm{K}, \mathrm{Na}, \mathrm{Ca}, \mathrm{Mg}$ and $\mathrm{N})$ in pepper (Capsicum annuum L.). Annals Agric. Sci., Ain Shams Univ., Cairo, 39(2), 699-707.

Ali, M.A., El-Gendy, R.S.S. and Ahmed, O.A. (2013) Minimizing adverse effects of salinity in vineyards. J. Horticultural Sci. \& Ornamental Plants, 5(1), 12-21.

Anjum, S.A., Wang, L., Farooq, M., Xue, L. and Ali, S. (2011) Fulvic acid application improves the maize performance under well-watered and drought conditions. J. Agron. Crop Sci. 10, 1469-1477.

Avron, M. (1960) Photophosphorylation by Swiss chard chloroplasts. Acta Biochim. Biophys. 40, 257-272.

Ayuso, M., Hernandez, T., Garcia, C. and Pascual, J.A. (1996) Stimulation of barley growth and nutrient absorption by humic substances originating from various organic materials. Bioresource Tech. 57, 251-257.

Baker, N.R. (2008) Chlorophyll fluorescence: A probe of photosynthesis in vivo. Annu. Rev. Plant Biol. 59, 89-113.

Baloğlu, M.C., Kavas, M., Aydın, G., Öktem, H.A. and Yücel, A.M. (2012) Antioxidative and physiological responses of two sunflower (Helianthus annuus) cultivars under PEG-mediated drought stress. Turk. J. Bot. 36, 707-714.

Basra, S.M.A., Afzal, I., Anwar, S., Shafique, M., Haq, A. and Majeed, K. (2005) Effect of different seed invigoration techniques on wheat (Triticum aestivum L.) seeds sown under saline and nonsaline conditions. J. Seed Technol. 28, 36-45.

Basra, S.M.A., Zahar, M., Rehman, H., Yassmin, A. and Munir, H. (2009) Evaluating the response of sorghum and Moringa leaf water extracts on seedling growth in hybrid maize. In: Proceedings of the International Conference on Sustainable Food Grain Production: Challenges and Opportunities. University of Agriculture, Faisalabad, Pakistan, p. 22. 
Basyouny, E.A., El.Borhamy, S.H. and Eisa, S.A. (2003) Response of corn plants grown on calcareous soil to organic fertilization and sulpher. Egypt. J. Appli. Sci. 18(9), 360-372.

Bernfeld, P. (1955) "Methods in Enzymmology". Vol. 1, pp. 149-154. Acad. Press, Inc; New York.

Black, C.A. (1968) "Soil Plant Relationships" (2 $2^{\text {nd }}$ ed.). John Wiley and Sons, NY, USA.

Chen, Y. and Aviad, T. (1990) Effect of humic substances on plant growth. In: "Humic Substances in Soil and Crop Sciences: Selected Readings", P. MC Carthy (Ed.), Am. Soc. Agron. Soil Sci. Soc. Am., Madison, Wisconsin, pp. 161-186.

Chen, Y.Y., Hu, C.Y. and Xiao, J.X. (2014) Effects of arbuscular mycorrhizal inoculation on the growth, zinc distribution and photosynthesis of two citrus cultivars grown in low-zinc soil. Trees, 28, 14271436.

Cimrin, K.M. and Yilmaz, I. (2005) Humic acid applications to lettuce do not improve yield but do improve phosphorus availability. Acta Agric. Scand. B. Soil Plant Sci. 55, 58-63.

Cimrin, K.M., Türkmen, O., Turan, M. and Tuncer, B. (2010) Phosphorus and humic acid application alleviate salinity stress of pepper seedlings. Afr. $J$. Biotechnol. 9, 5845-5851.

Desoky, E.M. and Merwad, A.M. (2015) Improving the salinity tolerance in wheat plants using salicylic and ascorbic acids. J. Agricultural Science, 7(10), 203-217.

Desoky, E.M., Merwad, A.M. and Elrys, A.S. (2017) Response of pea plants to natural bio-stimulants under soil salinity stress. American J. Plant Physiol. 12(1), 28-37.

Desoky, E.M., Merwad, A.M. and Rady, M.M. (2018) Natural biostimulants improve saline soil characteristics and salt stressed-sorghum performance. Communications in Soil Science and Plant Analysis, 49(8), 967-983.

Dillard, C.J. and German, J.B. (2000) Phytochemicals: Nutraceuticals and human health. J. Sci. Food Agric. 80, 1744-1756.

Elgharably, A.G. (2008) Nutrient availability and wheat growth as affected by plant residues and inorganic fertilizers in saline soils. Ph.D. Thesis. Soil and land Systems, Earth Environ. Sci., Univ. Adelaide, Aust. p.3.

Fadeels, A.A. (1962) Location and properties of chloroplasts and pigment determination in shoots. J. Plant Physiol. 15, 130-147.

Farooq, M., Wahid, A., Kobayashi, N., Fujita, D. and Basra, S.M.A. (2009) Plant drought stress: Effects, mechanisms and management. Agron. Sustain. Dev. 29, 185-212.

Farouk, M.G., Faisal, M.M.A. and Ibrahim, K.A. (2001) Response of wild mint (Mentha longifolia L. Huds. var. longifolia) plants to salinity stress. Egypt J. App. Sci. 16(4), 39-52.

Feinstien, R.N. (1949) Proborate as substrate in a new assay of catalase. J. Bio. Chem. 180, 1197-1202.

Foidle, N., Makkar, H.P.S. and Becker, K. (2001) The potential of Moringa oleifera for agricultural and industrial uses. p. 45-76. In: "The Miracle Tree: The Multipurpose Attributes of Moringa", L. Fuglie (Ed.). CTA Publications. Wageningen, the Netherlands.

Fu, Q.L., Meng, C.F. and Wu, Y.W. (1994) Effects of fulvic acid on the physiology and yield of rape (Brassica campestris L.). Oil Crops of China, 16 (2), 29-31.

Fuglie, L.J. (2000) The miracle tree: Moringa oleifera: Natural nutrition for the tropics. The Multiple Attributes of Moringa, p. 172. Rome: David Lubin Memorial Library, Food and Agriculture Organization of the U. N.

Galston, A.W. (1983) Polyamines as modulators of plant development. Bioscience, 33, 382-388.

Giri, B. and Mukerji, K.G. (2004) Mycorrhizal inoculant alleviates salt stress in Sesbania aegyptiaca and Sesbania grandiflora under field conditions: Evidence for reduced sodium and improved magnesium uptake. Mycorrhiza, 14, 307-312.

Hajar, A.S., Zidan, M.A. and Al-Zahrani, H.S. (1996) Effect of salinity stress on germination, growth and some physiological activity of Black cumin (Negella sativa) Arab Gulf. J. Sci. Res. 14(2), 445454. 
Hanafy, A.A.H., Nesiem, M.R., Hewedy, A.M. and Sallam, H.E. (2010) Effect of some simulative compounds on growth, yield and chemical composition of snap bean plants grown under calcareous soil conditions. J. Amer. Sci. 6, 10-16.

Hawker, M.M. and Walker, R.R. (1978) Effect of sodium chloride on expansion rates and invertase activity of leaves. Aust. J. Plant Physiol. 5, 73-80.

Horváth, E. , Csiszár, J., Gallé, Á., Poór, P., Szepesi, Á. and Tari, I. (2015) Hardening with salicylic acid induces concentration-dependent changes in abscisic acid biosynthesis of tomato under salt stress. J. Plant Physiology, 183, 54-63.

Howladar, S.M. (2014) Novel Moringa oleifera leaf extract can mitigate the stress effects of salinity and cadmium in bean (Phaseolus vulgaris L.) plants. Ecotoxicol. Environ. Saf. 100, 69-75.

Jackson, M.L. (1973) "Soil Chemical Analysis", pp. 144-197, 326-338. Prentice Hall Inc., Englewood Califfs, New Jersy.

Jagendorf, A.T. (1956) Oxidation and reduction of pyridine nucleotides by purified chloroplasts. Biochem. Biophys Acta, 40, 257-272.

Jianguo, Y., Shuiying, Y., Yujuan, Z. and Yingchang, S. (1998) Influence of humic acid on the physiological and biochemical indexes of apple trees. Forest Res. 11, 623-628.

Józef, S. and Szydełko, E. (2011) Growth rate and yields of a sorghum-sudangrass hybrid variety grown on a light and a medium-heavy soil as affected by cutting management and seeding rate. Polish J. Agronomy, 4, 23-28.

Kalaji, M.H. and Pietkiewicz, S. (1993) Salinity effect in plant growth and other physiological process. Acta Physiol. Plant, 15, 89-124.

Kilany, A.E., El-Shenawy, I.E., Abd El-Ghany, A.A. and Ahmed, O.A. (2006) Salt tolerance of some grape rootstocks. Research Bulletin, Ain Shams Univ. pp. 1-15.

Lechno, S., Zamski, E. and Tel, O. (1997) Salt stress induced responses in cucumber plants. J. Plant Physiol. 150(1), 206-211.

Lee, S.K. and Hacker, D.L. (2001) In vitro analysis of
RNA binding site within the N-terminal 30 amino acids of the Southern cowpea mosaic virus coat protein. Virology, 286, 317-327.

Levitt, J. (1980) Adaptation to salinity at the plant cell level. Plant and Soil, 89, 3-14.

Mackowiak, C.L., Grossl, P.R. and Bugbee, B.G. (2001) Beneficial effects of humic acid on micronutrient availability to wheat. Soil Sci. Soc. Amr. J. 65, 1744-1750.

Makkar, H.P.S. and Becker, K. (1996) Nutritional value and antinutritional components of whole and ethanol extracted of Moringa oleifera leaves. Animal Feed Science and Technology, 63(1- 4), 211-228.

Malibari, A.A., Aidan, M.A. and Heikal, M. M. (1993) Effect of salinity on germination and growth of alfalfa, Sunflower and Sorghum. Pak. J. Bot. 25 (2), 156-160.

Miller, G.L. (1959) Use of dinitro salicylic acid reagent for determination of reducing sugar. Ann. Chem. 31, 426-428.

Moyo, B., Masika, P., Hugo, A. and Muchenje, V. (2011) Nutritional characterization of Moringa (Moringa oleifera Lam.) leaves. Afr. J. Biotechnol. 10, 12925-12933.

Munns, R., and Tester, M. (20080 Mechanisms of salinity tolerance. Annu. Rev. Plant Biol., 59, 651681.

Nardi, S., Pizzeghello, D., Muscolo, A. and Vianello, A. (2002) Physiological effects of humic substances in plant growth. Soil Biol. Biochem. 34, 1527-1536.

Nieman, R.H. and Poulesn, L.L. (1967) Growth and synthesis of nucleic acid and protein by exised radish colyledons. Plant Physiol. 42, 946-952.

Nitsan, J. and Long, A. (1966) DNA synthesis the elongation non dividing cells of the lentil epicotyl and its production by gibberellin. Plant Physiology, 41, 956-970.

Nouman, W., Siddiqui, M.T., Basra, S.M.A., Farooq, H., Zubair, M. and Gull, T. (2013) Biomass production and nutritional quality of Moringa oleifera as field crop. Turk. J. Agric. For. 37, 410-419. 
Ouyang, B., Yang, T., Zhang, H., Li, Y., Zhang, J. and Fei, Z. (2007) Identification of early salt stress response genes in tomato root by suppression subtractive hybridization and microarray analysis. J. Exp. Bot. 58, 507-520.

Piper, C.S. (1950) "Soil and Plant Analysis". Interstice Publishers Inc. New York.

Pitman, M. and Läuchli, A. (2002) Global impact of salinity and agricultural ecosystems. In: "Salinity: Environment-Plants-Molecules", Läuchli, A.O., Lüttge, U. (Eds.), pp. 3-20. Kluwer Academic Publishers, Dordrecht.

Porcela, R., Redondo-Gómezb, S., Mateos-Naranjob, E., Arocaa, R., Garciac, R. and Ruiz-Lozanoa, J.M. (2015) Arbuscular mycorrhizal symbiosis ameliorates the optimum quantum yield of photosystem II and reduces non-photochemical quenching in rice plants subjected to salt stress. $J$. Plant Physiology, 185, 75-83.

Purr, A. (1950) Zur Bestimmung Pflanzlicher peroxidation. Biochemical Zieitschrift. Bd. 321(5), $1-18$.

Rady, M.M. and Hemida, K.A. (2016) Sequenced application of ascorbate-proline-glutathione improves salt tolerance in maize seedlings. Ecotoxicology and Environmental Safety, 133, 252-59.

Rady, M.M., Mohamed, G.F., Abdalla, A.M. and Ahmed, Y.H.M. (2015) Integrated application of salicylic acid and Moringa oleifera leaf extract alleviates the salt-induced adverse effects in common bean plants. Journal of Agricultural Technology, 11(7), 1595-1614.

Rady, M.M., Abd El-Mageed, T.A., Abdurrahman, H.A. and Mahdi, A.H. (2016 a) Humic acid application improves field performance of cotton (Gossypium barbadense L.) under saline conditions. Journal of Animal and Plant Science, 26(2), 487-93.

Reddy, M.P. and Varo, A.B. (1986) Changes in pigment composition, hill reaction activity and saccharides metabolism in bajra (Pennisetum typhoides $\mathrm{S} \& \mathrm{H}$ ) leaves $\mathrm{NaCl}$ salinity. Photosynthica, 20, 50-55.

Rehman, H., Nawaz, M.Q., Basra, S.M.A., Afzal, I., Yasmeen, A. and Hassan, F.U. (2014) Seed priming influence on early crop growth, phenological development and yield performance of linola (Linum usitatissimum L.). J. Integrative Agriculture, 13(5), 990-996.

Saruhan, V., Kusvuran, A. and Babat, S. (2011) The effect of different humic acid fertilization on yield and yield components performances of common millet (Panicum miliaceum L.). Sci. Res. Essays, 6, 663-669.

Sekmen, A.H., Özgür, R., Uzilday, B., Tanyolaç, Z.O. and Dinç, A. (2012) The response of the xerophytic plant Gypsophila aucherito salt and drought stresses: The role of the antioxidant defence system. Turk. J. Bot. 36, 697-706.

Semida, W.M., Taha, R.S., Abdelhamid, M.T. and Rady, M.M. (2014) Foliar-applied $\alpha$-tocopherol enhances salt-tolerance in Vicia faba L. plants grown under saline conditions. South African Journal of Botany, 95, 24-31.

Sharaky, M.M. (1982) The influence of CCC on DNA and RNA contents of cotton leaves and roots. Zagazig J. Agric. Res. 9(1), 123-131.

Sharif, M., Khattak, R.A. and Sarir, M.S. (2002) Effect of different levels of lignitic coal derived humic acid on growth of maize plants. Commun. Soil Sci. Plant Anal. 33, 3567-3580.

Sheng, M., Tang, M., Chen, H., Yang, B., Zhang, F. and Huang, Y. (2008) Influence of arbuscular mycorrhizae on photosynthesis and water status of maize plants under salt stress. Mycorrhiza, 18, 287-296.

Shigeoka, S., Ishikawa, T., Tamoi, M., Miyagawa, Y., Takeda, T., Yabuta, Y. and Yoshimura, K. (2002) Regulation and function of ascorbate peroxidase isoenzymes. J. Exp. Bot. 53, 1305-1319.

Siddhuraju, P. and Becker, K. (2003) Antioxidant properties of various solvent extracts of total phenolic constituents from three different agro climatic origins of drumstick tree (Moringa oleifera Lam.) leaves. J. Agric. Food Chem. 51, 2144 -2155.

Sivtrev, M.V., Panamoreva, L.E. and Akuzmetsova, K. (1973) Effect of salinization on chlorophylls activity in tomato leaves. Fiziol Rast. 20, 62-44.

Śliwiński, B. and Brzóska, F. (2008) Wykorzystaniekiszonek $\mathrm{z}$ sorgo w 
żywieniukrówmlecznych. 263-266. In: T. Michalski Problemy agrotech nikior azwykorzy staniakukury dzy i sorgo", UP Poznań.

Smironoff, N. (1993) The role of active oxygen in the response of plants to water deficit and desiccation. New Phytol. 125, 27-58.

Tattini, M., Bertoni, P., Laudi, A. and Traversi, M.L. (1991) Effect of humic acids on growth and biomass partitioning of container-grown olive. Acta Hort. 294, 75-80.

Ulukan, H. (2008 a) Effect of soil applied humic acid at different sowing times on some yield components in wheat (Triticum spp.) hybrids. Int. J. Botany, 4 (2), 164-175.

Ulukan, H. (2008 b) Tarla Bitkileri Tarımında Hümik Asit Uygulamas1, KSU Journal of Science and Engineering, 11(2), 119-128.

Von Wettestein, D. (1957) Chlorophyll-Lethal unddersubminkroskopische for mivechoel der plastiden. Exp. Cell. Res. 12, 427-433.

Yeo, A.R. and Flovers, T.J. (1983) Varietals differences in the toxicity of sodium ions in rice leaves. Physiol. Plant, 59,189-195.

Zhang, L., Gao, M., Zhang, L., Li, B., Han, M., Kumar, A.A. and Ashraf, M. (2013) Role of exogenous glycinebetaine and humic acid in mitigating drought stress-induced adverse effects in Malusrobusta seedlings. Turk. J. Bot. 37, 920-929.

Zhaoliang, L., Yueqing, S., Mingzhi, S., Yahong, S., Zi, L. and Mz, S. (1995) The effect of paclubotrazol on plant histology of some crops. Acta Agric. Shanghai. 11, 43-47.

Zhu, J.K. (2001) Plant salt tolerance. Trends Plant Sci. 6, 66-71.

(Received 24/12/2018; accepted 10/2/2019)

\section{استخدام المواد الدباية ومستخلص أوراق المورنجا لتحسين الأثار الضارة لملوحة التربة

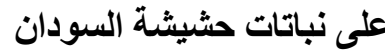

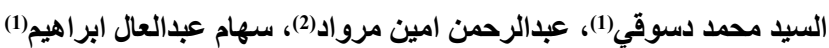

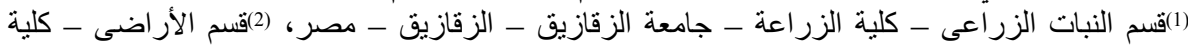 الزر اعة- جامعة الزقازيق - الزقازيق - مصر.}

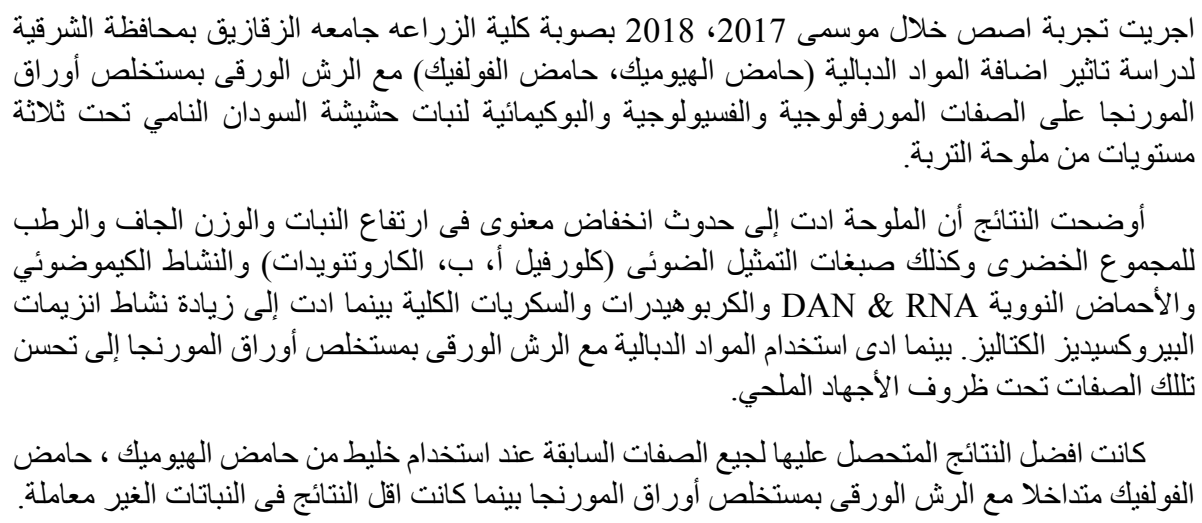

